\title{
Model systems to study the life cycle of human papillomaviruses and HPV-associated cancers
}

\author{
Louise T. Chow
}

Department of Biochemistry and Molecular Genetics, University of Alabama at Birmingham, Birmingham 35294-0005, USA

The prevalent human papillomaviruses (HPVs) infect either cutaneous or mucosal epithelium. Active Infections lead to epithelial hyperprolifeation and are usually cleared in healthy individuals within a year. Persistent infections in the anogenital tracts by certain high-risk genotypes such as HPV-16, HPV-18 and closely related types, can progress to high grade dysplasias and carcinomas in women and men, including cervical, vulva, penile and anal cancers. A significant fraction of the head and neck cancers are also caused by HPV-16. The viral oncogenes responsible for neoplastic conversion are E6 and E7 that disrupt the pathways controlled by the two major tumor suppressor genes, p53 and members of pRB family. Because HPV cannot be propagated in conventional submerged monolayer cell cultures, organotypic epithelial raft cultures that generate a stratified and differentiated epithelium have been used to study the viral life cycle. This article describes several systems to examine aspects of the viral productive phase, along with the advantages and limitations. Animal model systems of HPV carcinogenesis are also briefly described.

\section{KEYWORDS human papillomaviruses (HPVs); productive program; HPV-associated cancers;} model systems

\section{INTRODUCTION}

Human papillomaviruses (HPVs) are prevalent pathogens with strict species and tissue tropisms. Over 200 types of HPVs infect either mucosal or cutaneous epithelium (Bravo and Felez-Sanchez 2015; Bzhalava et al., 2015). Many of them are ubiquitous and are considered as part of normal human condition. Most infections are asymptomatic, while active infections cause warty epithelial proliferation; they are usually cleared within a year by the patient's immune systems. However, a small fraction of persistent infections in the anogenital tracts by about 2 dozens mucosotropic high-risk (HR) $\alpha$ HPV

Received: 21 April 2015, Accepted: 21 April 2015

Published online: 23 April 2015

$\triangle$ Correspondence:

Phone: +1-205- 975-8300

Email: Itchow@uab.edu

ORCID: 0000-0001-7586-9569 types, such as type 16, and type 18 and closely related types, can progress to high grade dysplasias, carcinoma in-situ and cancer, most notably cervical, vulva, penile, and anal cancers. Indeed, over $99 \%$ of the cervical cancers are associated with one or more of these HR HPV types (Walboomers et al., 1999). About 25\%-35\% of head and neck cancer, notably oropharyngeal cancers, are also caused by HPV-16. Some lung cancers have been reported to harbor and express HR HPV oncogenes (Buonomo et al., 2011). In contrast, types 6 and 11 cause over $90 \%$ of genital warts and virtually all the laryngeal papillomatosis. Such lesions rarely progress to cancers (zur Hausen, 2009). Because the mucosotropic $\alpha \mathrm{HPV}$ types can be sexually transmitted, they have commanded the attention of most of the basic research efforts and clinical translation into vaccine development, patient screening, and therapeutic strategies.

HPVs produce few virus particles in the infected tissues and attempts to produce viruses in conventional monolayer cell cultures have been unsuccessful. An 
examination of a wide spectrum of patient lesions, from benign to cancerous, revealed the reasons why. In benign productive warty lesions, viral transcription and viral DNA amplification as extrachromosomal plasmids were tightly associated with squamous differentiation, and virus capsid antigen was detected only in the superficial dying or dead cells (Stoler et al., 1989). In high grade lesions and cancers, HPV DNA was often found integrated into the host chromosomes. The expression of viral E6 and E7 genes was highly upregulated, whereas the late genes are not expressed and progeny viruses are no longer produced (Stoler et al., 1992; Chow and Broker, 2013). Thus, prior to the successful establishment of a productive system, studies were concentrated in investigating functions of individual viral proteins in transient transcription or replication assays or in investigating the immortalization functions of the HR HPVs. These studies establish that initiation of replication from the viral origin (ori) depends on the ori recognition protein E2 and the replicative DNA helicase E1 and that the HR HPV E6 and E7 oncoproteins disrupt the pathways controlled by the two major tumor suppressors, p53 and the pRB family of proteins, as well as by many additional host proteins. Together, the viral oncogenes immortalize primary human keratinocytes or cervical cells in vitro (McLaughlin-Drubin and Münger, 2009; Münger Moody and Laimins, 2010; Chow and Broker, 2013) and are responsible for viral carcinogenesis in transgenic mice (to be described).

To elucidate the roles of the viral oncoproteins in the viral life cycle and the detailed molecular mechanisms, it is necessary to recapitulate the viral productive phase in vitro. To this end, researchers turned to an organotypic raft culture system which was developed by dermatologists to obtain quickly simple epithelial tissues in large quantities for burnt patients (Asselineau and Prunieras, 1984). This system was adapted to achieve a faithful and orderly program of proliferation, stratification and terminal squamous differentiation (Wilson et al., 1992). Briefly, primary human epithelial cells were plated over a dermal equivalent comprising type 1 rat tail collagen embedded with mouse J2 3T3 fibroblasts as feeder cells. The assembly is then cultured on top of a stainless grid at the air-liquid medium interface. Over a period of 9 days to 3 weeks, the epithelial cells develop into a stratified squamous epithelium. This culture system supported the viral productive program based on explanted warty tissues that were developed from HPV-11 infected foreskin chips grafted under the renal capsule of nude mice (Dollard et al., 1992). Meyers et al. (1992) on the other hand developed raft cultures from a cell line CIN 612 derived from a cervical dysplasia (Bedell et al., 1991). Upon treatment with TPA to promote abrupt terminal differentiation, progeny virus particles were generated.
At this junction, it is appropriate to mention briefly that raft cultures can also be developed from PHKs transduced with retroviruses that deliver viral oncogenes to investigate their functions (Halbert et al., 1992; Cheng et al., 1995; Genovese et al., 2008, 2011). Furthermore, certain cervical carcinoma cells lines such as $\mathrm{SiHa}$ and CaSki as well as keratinocytes that are at various stages of transformation by transfected HR HPV DNA. These raft cultures simulate cancer tissues and the different grade of dysplasias, respectively (Blanton et al., 1991; Hurlin et al., 1991; Steenbergen et al., 1998; Henken et al., 2011).

\section{ORGANOTYPIC EPITHELIAL RAFT CULTURE SYSTEMS CAPABLE OF PRODUCING VIRUS PARTICLES}

\section{Immortalized epithelial cells}

Immortalized epithelial cell lines derived from cervical dysplasias, such as W12 (Stanley et al., 1989), which harbor HPV-16 genomic plasmids, or CIN612 which harbors HPV-31b plasmids (Hummel et al., 1992) were used to investigate virus-host interactions in raft cultures. But to study viral mutants, one has to use cells that do not have resident HPV DNA. For that, NIKS, a spontaneously immortalized human dermal keratinocytes (Lynn-Hoffmann et al., 2000) or PHKs immortalized by the transfected HR HPV DNA (wild type or mutant) are widely used (Lambert et al., 2005; McLaughlin-Drubin and Meyers, 2005; Regan and Laimins, 2013). However, robust viral DNA amplification and high titer of progeny viruses have not been reported in raft cultures of immortalized cells, compromising their use in mutagenic analyses. The difference relative to primary human keratinocytes (see below) is undoubtedly caused by unfavorable genetic or epigenetic changes associated with the immortalization process.

\section{Primary human foreskin keratinocytes (PHKs)}

Being readily available, primary keratinocyte cultures derived from foreskins circumcisions (PHKs) are most frequently used to develop organotypic cultures. The epithelium developed resembles cutaneous skin with basal, spinous, granular and cornified strata. Cervical cells can also be developed into raft cultures with histology distinct for cervical tissues. However, because normal cervix tissue is not routinely available and the lack of tissue consistency due to differences in donor age or other conditions unrelated to HPV infections, it is not used routinely, except for the purpose of obtaining immortalized cells.

The one highly productive program uses early passages of PHKs in which HPV-18 plasmid DNA is generated in the transfected PHKs by using the Cre-LoxP recombination system. The viral plasmid liberated from 
the supercoiled parental recombinant plasmid retains its superhelicity and serves as efficient templates for transcription and DNA replication. A differentiation-dependent productive program is recapitulated in the epithelial tissue in 2 weeks. The viral DNA can amplify to an average over 5000 copies/cell. Progeny virus particles are assembled in the superficial cells and matured in the dying or dead cells. High titer of progeny virions harvested are infectious, enabling passage in PHKs raft cultures (Wang et al., 2009). The progeny virus has been used to help assess the efficacy of next generation prophylactic vaccines (Jagu et al., 2013).

The Cre-loxP based system has enabled genetic analyses of HPV-18 mutants not previously possible. For instance, the HR HPV E6 proteins interact and destabilize a large number of host proteins, including p53 (Howie et al., 2009). The expression of E7 induces a DNA damage-like response whereupon ATM, CHK1, CHK2 and JNK kinases are activated (Moody and Laimins, 2009; Banerjee et al., 2011). Being a substrate of these kinases, p53 protein is stabilized in the suprabasal cells (Jian et al., 1998). E6 mutants unable to destabilize p53 cannot be investigated in raft cultures because they do not immortalize keratinocytes and also because mutant genomes are quickly lost in transfected cells. Using the Cre-loxP system in PHKs, p53 is shown to be one of the crucial targets of the E6 protein. HPV-18 E6 mutants unable to destabilize p53 effectively are impaired in viral DNA amplification, while p53 shRNA, which reduces p53 protein levels, largely restores it (Kho et al., 2013).

\section{EV keratinocytes}

Epidermodysplasia verruciformis (EV) patients are genetically recessive in chromosomal EVER1 or EVER2 genes. Mutations in either gene make the subjects highly susceptible to cutaneous $\beta$ HPV infections. EV patients are very rare but lesions associated with HPV 5 or 8 , convert to non-melanoma, squamous carcinomas in sun exposed skins at a rate of 35\%. EVER1 and EVER2 genes encode proteins that control $\mathrm{Zn}^{2+}$ homeostasis (Lazarczyk et al., 2009). The authors propose that the proteins encoded by these two genes provide protection against HPVs by limiting viral proteins the access to $\mathrm{Zn}^{2+}$. Nevertheless, raft cultures of EV patient keratinocytes are hyperproliferative and, in some cases, exhibit a differentiation dependent viral DNA amplification, analogous to $\alpha$ HPV types (Borgogna et al., 2012). Clearly EV patient tissues are too rare to be used as routine research materials. It will be interesting to determine whether knockdown EVER genes in PHKs would facilitate the productive phase of HPV-5 or HPV-8 in raft cultures.

\section{Advantages of organotypic raft cultures}

One of the many advantages of raft cultures is the ability to interrogate the virus-host interaction in the stratified epithelium in individual cells by using in situ assays of thin section of formalin-fixed, paraffin embedded epithelial tissues. This system can be subjected to metabolic labelling, time course, pulse chase experiments, and varying multiplicity of infection. Using these approaches the productive program of HPV-18 was elucidated (Wang et al., 2009). In brief, in situ assays show that the viral E7 protein destabilizes p130, a pRB family protein which maintains the homeostasis of post-mitotic differentiated cells, thereby promoting S phase re-entry (Genovese et al., 2008, 2011). While the cellular DNA replicates in $\mathrm{S}$ phase, as evidence by the presence nuclear $\mathrm{S}$ phase cyclin $\mathrm{A}$, the viral DNA amplifies during a E7-induced prolonged G2 phase (Banerjee et al. 2011), where high amounts of $\mathrm{G} 2$ phase cyclin B1 accumulate in the cytoplasm. As the viral DNA amplifies in the mid and upper cell strata, the E7 activity is gradually reduced and is eventually extinguished, whereupon cells exit the cell cycle. Thereafter, both viral and host DNA replication cease, and the virus switches to a late phase for virion morphogenesis.

Conventional biochemical assays can be conducted on the epithelial portion of the raft cultures, including virus isolation and titering by $\mathrm{qPCR}$, protein isolation for immunoprecipitation, co-immunoprecipitation, or Western blots, and nucleic extraction for Southern blots, qPCR, Northern blots and RT-PCR. For instance, cDNA cloning, Northern blots and RT-PCR of the raft cultures lysates have established a detailed viral transcription map (Wang et al., 2011; Kho et al., 2013). The PHK raft cultures system can also be used to assess the effects of potential inhibitors of virus infection. Cytotoxicity is readily revealed by changes in tissue histology in HPVinfected and control normal raft cultures in the presence or in the absence of the test compound. The extent of inhibition of viral DNA amplification can be evaluated by in situ hybridization and the average viral DNA copy number/per cell can be quantified by qPCR. Moreover, the mechanisms of action can be investigated in situ or biochemically (unpublished results of our laboratory). We suggest that it would be a more expedient and less expensive substitute than xenografts of HPV infected tissue in SCID mice (Bonnez, 2005).

Importantly, raft cultures uniquely offer the opportunity to analyze epithelial tissues in the absence of other cell or tissue types, as is the case for native tissues from patients. An example is the investigation of alterations in the microRNA (miRNA) expression in response to HPV infection. miRNAs are regulatory, noncoding small RNAs that down-regulate protein expression of targeted mRNAs. Thus miRNAs could be either tumorigenic or tumor suppressive. HPVs do not encode miRNAs but, by targeting host proteins, E6 or E7 can alter indirectly the expression 
of host encoded miRNAs. The effects have been documented in viral oncogene transduced PHKs or in cancer cell lines that harbor HR HPVs (Martinez et al., 2008; Wang et al., 2008, 2009; Wald et al., 2011; Zheng and Wang, 2011; Yablonska et al., 2013; McKenna et al., 2014). Not unexpectedly, some alterations in miRNA expression appear to facilitate viral productive program (MelarNew and Laimins 2010; Gunasekharan and Laimins, 2013). Conversely, viral oncogene expression can also be affected by miRNA induced by antiviral responses of the infected host cells (Zhang et al., 2013).

Several studies have profiled miRNAs in cervical cancers and in head and neck cancers. It has been proposed that certain changes may serve as prognostic biomarkers for HPV-associated lesions (Martinez et al., 2008; Shishodia et al., 2014; Honegger et al., 2015). However, to demonstrate the relationship between miRNA modulation and HPV activities, it is necessary to interrogate with in vitro model system to compare HPV infected cells or tissues relative to normal cells or tissues, while unencumbered by the limitations of patient tissues, such as the presence of other cell types (fibroblasts, endothelial cells, as well as immune cells), possible inclusion of normal tissues, or coexistence of different grades of HPV lesions.

Raft cultures are ideal to examine the modulation of miRNA expression as a consequence of HPV infection. In a recent study, changes in the expression of a number of miRNAs were found to be common in raft cultures of immortalized keratinocytes or cervical cells containing HPV-16 or HPV-18 and in HPV-18 productively infected PHK raft cultures (Wang et al., 2014). The viral proteins responsible were identified to be E6, E7 or both. The ratio of several miRNAs the expression of which was most prominently altered tracks with HPV carcinomas. However the caveat in assaying patient specimens is the mixed cell or tissue types, as noted above. Whether the altered expression of these miRNAs identified in this and other studies indeed serve as specific biomarkers for HPV lesion progression needs to be validated with additional patient specimens or with raft cultures of immortalized PHKs at different stages of transformation.

\section{The limitations of organotypic raft cultures}

There are limitations in PHK organotypic cultures. First, early passages of PHKs have to be used and the efficiencies of DNA transfection can vary among batches of PHKs. Thus, it can be time consuming, but not more so than deriving HR HPV immortalized cells in vitro. Second, in situ detection for host or viral proteins are limited by the availability of antibodies that can function in formalin fixed tissues. Third, it has not been possible to deliver double-stranded siRNAs to raft cultures, likely due to nonspecific binding to the dermal equivalent (our unpublished observation). However, retroviral vectors expressing shRNA have been successfully transduced into PHKs prior to raft cultures development (Lee et al., 2011; Kho et al., 2013). Lastly, because of the relative long duration of these experiments, it is not possible to knockdown with high efficiency host proteins that are critical for basal cell proliferation, necessary to sustain the raft cultures.

\section{IN VITRO MODEL SYSTEMS THAT DO NOT PRODUCE PROGENY VIRUS}

\section{Epithelial cells}

Human keratinocytes are known to undergo abrupt differentiation within 1 to 3 or 4 days when they were cultured while being suspended in methylcellulose (Adams and Watt, 1989) or in the presence of high $\mathrm{Ca}^{2+}$ (Boyce and Ham, 1983; Stanley and Yuspa, 1983). To shorten the duration of the experiments and to streamline and facilitate biochemical assays, these alternative approaches have been applied to epithelial cells containing HR HPV genomic plasmids (Regan and Laimins, 2013). However, in the absence of sequential stratification and orderly differentiation, the viral DNA amplification is limited. Since capsid protein expression is dependent on high levels of viral DNA amplification (Wang et al., 2009, Kho et al., 2013), it is not detected and progeny virus particles are not produced. Thus, certain aspects of the viral productive program cannot be investigated.

On the other hand, there are advantages of these systems. They dramatically speed up the conduct of the experiments. The effects of siRNAs to knockdown certain host proteins can be easily tested without having to construct shRNA-producing retroviruses. Chemical inhibitors that would affect cell proliferation and hence cannot be tested in long-term raft cultures can be examined in these short term cultures. By using these systems, a number of host proteins or pathways have been shown to play a role in the viral life cycle (Hong et al., 2011; Hoskins et al, 2012; Donaldson et al., 2013; Hong and Laimins, 2013, 2015). It would be most desirable if some of these experiments can be extended to PHK raft cultures for comparison.

\section{U2OS cell line}

U2OS is an osteosarcoma cell line and been shown to maintain transfected HPV DNA as extra-chromosomal plasmids. The HR and LR $\alpha$ HPVs and the cutaneous beta papillomavirus are stably maintained for several weeks (Geimanen et al., 2011; Sankovski et al., 2014). This system has been used to study the initial viral DNA replication upon introduction into the cells and its regulation by viral proteins. The viral promoters and mRNA splicing sites are similar to what has been reported in 
productive HPV infections. Also of interest is the observation that the viral DNA copy number increases when the cells were cultured for many days at a confluent state without passage. However, the increase in viral DNA copy number is limited and there is no capsid protein synthesis, nor progeny virus production. The investigators propose that this system will be useful for screening inhibitors of HPV replication.

\section{A trophoblasts}

HPV DNA has been detected in cord blood and placental trophoblasts. Its presence increases HPV positivity in neonates and is also associated with preterm spontaneous delivery. These observations were attributed to HPV-induced dysfunction of the placenta (Sarkola et al., 2008; Gomes et al., 2008). Thus, it is of interest to describe experiments in which HPV DNA was transfected into trophoblasts. The 3A trophoblast cell line is derived by immortalizing human trophoblasts with a temperature sensitive SV40 T antigen which is inactivated by culturing the cells at $39^{\circ} \mathrm{C}$ during the experiments. This cell line has been reported to support the productive program of HR and LR HPV types (Liu et al., 2005; You et al., 2008). However, viral DNA copy number appears low and decreases with time. Further careful characterization is needed to assess its potential as a model system to study the HPV infectious program.

\section{ANIMAL MODEL SYSTEMS TO EXAMINE HPV CARCINOGENESIS}

\section{Transgenic mice}

The HR HPV E6 and E7 genes can immortalize primary human epithelial cells in which the viral DNA is integrated into the host chromosomes. These cells are not tumorigenic in immune-compromised mice. Tumorigenic properties eventually emerge upon prolonged propagation of the immortalized cells under selective pressure to become sequentially growth factor independent and differentiation resistant (Creek et al., 1995). Genetic or epigenetic changes occurred in cellular genes during this multi-stage transformation processes. The identification of these host genes is a subject of intense ongoing research (Henken et al., 2011; Chen et al., 2013; Schütze et al., 2015; Xu et al., 2015).

To investigate HPV carcinogenesis in animal model systems, transgenic mice have long been used. The viral oncogenes E6, E7, or E5 of HPV-16, or the entire early region of HPV16 are expressed from the keratin 14 promoter which is active only in the basal cells of the mouse epithelium. Bitransgenic HPV-16 E6 and E7 mice were then obtained by breeding the single transgenic mice. Interestingly, cancers develop only upon prolonged exposure to estrogen which promotes cell proliferation.
Constitutive expression of viral oncogenes in the proliferating basal cells usurps the pRB- and p53-regulated pathways, thereby leading to genome instability while curbing p53 mediated apoptosis. Ultimately, progression to carcinomas occurs. Cancers of the cervix, anus and head and neck have all been modeled (Ocadiz-Delgado et al., 2009; Jabbar et al., 2009; Maufort et al., 2010; Stelzer et al., 2010; Thomas et al., 2011).

The HPV transgenic mice can be further bred with various mutant mice and used to examine addtional pathways involved in HPV carcinogenesis. For Instance, a functional estrogen receptor $\alpha$ is shown to be essential for the development of cervical cancer (Son et al., 2014). This finding supports the need for long term exposure to estrogen. Conversely, an ER antagonist can clear mice of HPV-induced cervical cancer (Chung and Lambert, 2009). Other double transgenic mice show that Wnt/ $\beta$-catenin signaling (Bulut and Üren, 2015) and Fanconi anemia deficiency promote viral carcinogenesis (Park et al., 2013, 2014). It is worth noting that because the transgenic mice are immune competent, they are also being used to investigate interactions of HPV with the mice immune systems (Gosmann et al., 2014a, 2014b; Tran et al., 2014).

In contrast to HR $\alpha$ HPVs, for which the expression of viral oncogenes is invariably detected in associated cancers and indeed necessary to maintain transformed phenotypes, the causal relationship between $\beta$ HPVs and non-melanoma squamous carcinoma is more difficult to prove except for EV patients where cancers are usually associated with HPV-5 or HPV-8. This is because viral DNA and RNA are not detected in all the cancer cells. Furthermore, the large number of EV family of $\beta$ HPVs is commonly found in healthy subjects. Thus, carcinogenesis by these viruses in non-EV patients may involve additional mechanisms (Howley and Pfister, 2015).

Transgenic mice models reveal that E6 and E7 oncogenes of HPV-38 function as tumor promoters and collaborate with chemical carcinogens such as DMBA or TPA, or with DNA damaging agent, such as UV, to promote progression, increasing susceptibility to developing skin cancers (Viarisio et al., 2013). Interestingly, in HPV8 transgenic mice, UV irradiation elevates viral oncogene expression, which in turn up-regulates oncogenic miRNAs and down-regulates tumor suppressive miRNAs (Hufbauer et al., 2011).

\section{Xenografts of cervical cancer cell lines and patient derived xenografts in immune compromised mice}

As with other kinds of cancer cell lines, cervical cancer cell lines can be grown as xenografts in flanks of athymic mice. In recent years, investigators have had success in grafting fragments of cervical cancer tissues 
orthotopically (patient derived orthotopic xenografts) or more commonly, in the flanks of SCID mice (Siolas and Hannon, 2013; Hiroshima et al., 2015). The tumors developed can be serially passaged in immune compromised mice. These xenolines, once established, offer advantages over cervical carcinoma cell lines because they retain characteristics more closely resemble the original cancers. In contrast, cancer cell lines that have been propagated in vitro for years could have properties unlike the original cancers. The xenolines can be used in experiments aimed to deliver personalized medicine. For instance, profiling the patient cancers to identify biomarkers (Ojesina et al., 2014; Cancer Genome Atlas Network. 2015; Chung et al., 2015) would guide the selection of the pathway-dependent small molecular weight inhibitors. The potential therapeutic effects of the inhibitors can be tested and verified in the patient-derived xenografts. Positive results may then form the basis for moving towards clinical trials.

\section{HPV-16 Transformed mouse cells in syngenic mice}

TC- 1 cells are $\mathrm{C} 57 \mathrm{BL} / 6$ mouse lung cells that are transformed by HPV-16 E6/E7 genes and activated c-Ha-Ras (Lin et al., 1996). The cells are tumorigenic in syngeneic mice. Because C57BL/6 mice is immune competent, it is very widely used in the development of immune therapy to treat HPV-caused cancers and in testing potential therapeutic agents (Jung et al., 2014; Peng et al., 2015; also see references therein).

\section{CONCLUDING REMARKS}

To summarize, in vitro and in vivo model systems have been developed to examine all aspects of the HPVassociated diseases, from benign infections to cancers. The productive program is best addressed by in vitro systems, as is the multi-stage transformation process. The transgenic model system provides the platform to investigate the mechanisms of HPV carcinogenesis in each of the sites where the HR HPVs cause cancers. Upon gaining a thorough understanding of viral pathogenesis, both the in vitro and in vivo model systems can be employed for drug discovery. Unlike xenografts in immune compromised mice or cell or raft cultures, transgenic mice also offer an opportunity to investigate immunological interactions between host and HPVs. Finally, the patient derived xenograft model most closely mimics the original cancers. It could play an important role in delivering personalize medicine.

\section{ACKNOWLEDGMENTS}

The research in the author's lab has been supported by grants from the Cancer Institutes of the National Institute of Health. Current funding comes from CA 83679 and from the Anderson Family Endowed Chair in Medical Education, Research and Patient Care. She thanks current and past lab members for their contributions in moving research projects forward. She also acknowledges the many colleagues with whom she has the privilege to collaborate, especially Dr. Thomas R Broker, for his scientific insights and unfailing support in the lab and at home.

\section{COMPLIANCE WITH ETHICS GUIDELINES}

The author declares no conflict of interest. This article does not contain any studies with human or animal subjects.

\section{REFERENCES}

Adams JC, Watt FM. 1989. Fibronectin inhibits the terminal differentiation of human keratinocytes. Nature, 340: 307-309.

Allen-Hoffmann BL, Schlosser SJ, Ivarie CA, Sattler CA, Meisner LF, O'Connor SL. 2000. Normal growth and differentiation in a spontaneously immortalized near-diploid human keratinocyte cell line, NIKS. J Invest Dermatol, 114: 444-455.

Asselineau D, Prunieras M. Reconstruction of 'simplified' skin: control of fabrication. 1984. Br J Dermatol, 111 Suppl 27: 219222.

Banerjee NS, Wang HK, Broker TR, Chow LT. 2011. Human papillomavirus (HPV) E7 induces prolonged G2 following S phase reentry in differentiated human keratinocytes. J Biol Chem, 286: 15473-115482.

Bedell MA, Hudson JB, Golub TR, Turek ME, Hosken M, Wilbanks GD, Laimins LA. 1991. Amplification of human papillomavirus genomes in vitro is dependent on epithelial differentiation. J Virol, 65: 2254-2260.

Blanton RA, Perez-Reyes N, Merrick DT, McDougall JK. 1991. Epithelial cells immortalized by human papillomaviruses have premalignant characteristics in organotypic culture. Am J Pathol, 138: 673-685.

Bonnez W. 2005. The HPV xenograft severe combined immunodeficiency mouse model. Methods Mol Med, 119: 203-216.

Borgogna C, Zavattaro E, De Andrea M, Griffin HM, Dell'Oste V, Azzimonti B, Landini MM, Peh WL, Pfister H, Doorbar J, Landolfo S, Gariglio M. 2012. Characterization of beta papillomavirus E4 expression in tumours from Epidermodysplasia Verruciformis patients and in experimental models. Virology, 423: 195-204.

Boyce ST, Ham RG. 1983. Calcium-regulated differentiation of normal human epidermal keratinocytes in chemically defined clonal culture and serum-free serial culture. J Invest Dermatol, $81: 33 \mathrm{~s}-40 \mathrm{~s}$.

Bravo IG, Félez-Sánchez M. 2015. Papillomaviruses: Viral evolution, cancer and evolutionary medicine. Evol Med Public Health, 1: 32-51.

Bulut G, Üren A. 2015. Generation of k14-e $7 / \Delta$ n $87 \beta$ cat double transgenic mice as a model of cervical cancer. Methods Mol Biol, 1249: 393-406.

Buonomo T, Carraresi L, Rossini M, Martinelli R. 2011. Involvement of aryl hydrocarbon receptor signaling in the development of small cell lung cancer induced by HPV E6/E7 oncoproteins. J Transl Med, 2011 9: 2. 
Bzhalava D, Eklund C, Dillner J. 2015. International standardization and classification of human papillomavirus types. Virology, 476: 341-344.

Cancer Genome Atlas Network. 2015. Comprehensive genomic characterization of head and neck squamous cell carcinomas. Nature, 517: 576-582.

Chen Y, Pirisi L, Creek KE. 2013. Ski protein levels increase during in vitro progression of HPV16-immortalized human keratinocytes and in cervical cancer. Virology, 444: 100-108.

Cheng S, Schmidt-Grimminger DC, Murant T, Broker TR, Chow LT. 1995. Differentiation-dependent up-regulation of the human papillomavirus E7 gene reactivates cellular DNA replication in suprabasal differentiated keratinocytes. Genes Dev, 9: 23352349.

Chow LT, Broker TR. 2013. Human papillomavirus infections: warts or cancer? Cold Spring Harb Perspect Biol, 5: a012997.

Chung SH, Lambert PF. 2009. Prevention and treatment of cervical cancer in mice using estrogen receptor antagonists. Proc Natl Acad Sci U S A, 106: 19467-19472.

Chung TK, Van Hummelen P, Chan PK, Cheung TH, Yim SF, Yu MY et al. 2015. Genomic aberrations in cervical adenocarcinomas in Hong Kong Chinese women. Int J Cancer, Jan 27. doi: 10.1002/ijc. 29456

Creek KE, Geslani G, Batova A, Pirisi L. 1995. Progressive loss of sensitivity to growth control by retinoic acid and transforming growth factor-beta at late stages of human papillomavirus type 16-initiated transformation of human keratinocytes. Adv Exp Med Biol, 375: 117-135.

Dollard SC, Wilson JL, Demeter LM, Bonnez W, Reichman RC, Broker TR, Chow LT. 1992. Production of human papillomavirus and modulation of the infectious program in epithelial raft cultures. Genes Dev, 6: 1131-1142.

Donaldson MM, Mackintosh LJ, Bodily JM, Dornan ES, Laimins LA, Morgan IM. 2013. An interaction between human papillomavirus $16 \mathrm{E} 2$ and TopBP1 is required for optimum viral DNA replication and episomal genome establishment. J Virol, 86: 12806-12815.

Gosmann C, Frazer IH, Mattarollo SR, Blumenthal A. 2014a. IL-18, but not IL-12, induces production of IFN- $\gamma$ in the immune-suppressive environment of HPV16 E7 transgenic hyperplastic skin. J Invest Dermatol, 134: 2562-2569.

Gosmann C, Mattarollo SR, Bridge JA, Frazer IH, Blumenthal A. 2014b. IL-17 suppresses immune effector functions in human papillomavirus-associated epithelial hyperplasia. J Immunol, 193: 2248-2257.

Geimanen J, Isok-Paas H, Pipitch R, Salk K, Laos T, Orav M, Reinson T, Ustav M Jr, Ustav M, Ustav E. 2011. Development of a cellular assay system to study the genome replication of highand low-risk mucosal and cutaneous human papillomaviruses. J Virol, 85: 3315-3329.

Genovese NJ, Banerjee NS, Broker TR, Chow LT. 2008. Casein kinase II motif-dependent phosphorylation of HPV E7 protein promotes p130 degradation and S-phase induction in differentiated human keratinocytes. J Virol, 82: 4862-4873.

Genovese NJ, Broker TR, Chow LT. 2011. Nonconserved lysine residues attenuate the biological function of the low-risk human papillomavirus E7 protein. J Virol, 85: 5546-5554.

Gomez LM, Ma Y, Ho C, McGrath CM, Nelson DB, Parry S. 2008. Placental infection with human papillomavirus is associated with spontaneous preterm delivery. Hum Reprod, 23: 709-715.

Gunasekharan V, Laimins LA. 2013. Human papillomaviruses modulate microRNA 145 expression to directly control genome amplification. J Virol, 87: 6037-6043.

Halbert CL, Demers GW, Galloway DA. 1992. The E6 and E7 genes of human papillomavirus type 6 have weak immortalizing activity in human epithelial cells. J Virol, 66: 2125-2134.

Henken FE, Banerjee NS, Snijders PJ, Meijer CJ, De-Castro Arce J, Rösl F, Broker TR, Chow LT, Steenbergen RD. 2011. PIK3CA-mediated PI3-kinase signaling is essential for HPV-induced transformation in vitro. Mol Cancer, 10: 71.

Hiroshima Y, Zhang Y, Zhang N, Maawy A, Mii S, Yamamoto M, Uehara F, Miwa S, Yano S, Murakami T, Momiyama M, Chishima T, Tanaka K, Ichikawa Y, Bouvet M, Murata T, Endo I, Hoffman RM. 2015. Establishment of a patient-derived orthotopic Xenograft (PDOX) model of HER-2-positive cervical cancer expressing the clinical metastatic pattern. PLoS One, 10: e0117417.

Honegger A, Schilling D, Bastian S, Sponagel J, Kuryshev V, Sültmann H, Scheffner M, Hoppe-Seyler K, Hoppe-Seyler F. 2015. Dependence of Intracellular and Exosomal microRNAs on Viral E6/E7 Oncogene Expression in HPV-positive Tumor Cells. PLoS Pathog, 11: e1004712.

Hong S, Dutta A, Laimins LA. 2015. The acetyltransferase tip60 is a critical regulator of the differentiation-dependent amplification of human papillomaviruses. J Virol, 89: 4668-4675.

Hong S, Laimins LA.2013. The JAK-STAT transcriptional regulator, STAT-5, activates the ATM DNA damage pathway to induce HPV 31 genome amplification upon epithelial differentiation. PLoS Pathog, 9: e1003295.

Hong S, Mehta KP, Laimins LA. 2011. Suppression of STAT-1 expression by human papillomaviruses is necessary for differentiation-dependent genome amplification and plasmid maintenance. J Virol, 85: 9486-9494.

Hoskins EE, Morreale RJ, Werner SP, Higginbotham JM, Laimins LA, Lambert PF, Brown DR, Gillison ML, Nuovo GJ, Witte DP, Kim MO, Davies SM, Mehta PA, Butsch Kovacic M, Wikenheiser-Brokamp KA, Wells SI. 2012. The fanconi anemia pathway limits human papillomavirus replication. J Virol, 86: 8131-8138.

Howley PM, Pfister HJ. 2015. Beta genus papillomaviruses and skin cancer. Virology, Feb 24. pii: S0042-6822(15)00047-1. doi: 10.1016/j.virol.2015.02.004.

Howie HL, Katzenellenbogen RA, Galloway DA. 2009. Papillomavirus E6 proteins. Virology, 384: 324-334.

Hufbauer M, Lazić D, Reinartz M, Akgül B, Pfister H, Weissenborn SJ. 2011. Skin tumor formation in human papillomavirus 8 transgenic mice is associated with a deregulation of oncogenic miRNAs and their tumor suppressive targets. J Dermatol Sci, 64: 7-15.

Hurlin PJ, Kaur P, Smith PP, Perez-Reyes N, Blanton RA, McDougall JK. 1991. Progression of human papillomavirus type 18-immortalized human keratinocytes to a malignant phenotype. Proc Natl Acad Sci U S A, 88: 570-574.

Jabbar S, Strati K, Shin MK, Pitot HC, Lambert PF. 2010 Human papillomavirus type 16 E6 and E7 oncoproteins act synergistically to cause head and neck cancer in mice. Virology, 407: 60-67.

Jagu SJ, K Kwak, Schiller JT, Lowy DR, Kleanthous H, Kalnin K, Wang HK, Chow LT, Huh WK, Jaganathan K, Chivukula S, Roden RB. 2013. Phylogenetic considerations in designing a broadly protective multimeric L2 vaccine. J Virol, 87: 61276136.

Jian Y, Schmidt-Grimminger DC, Chien WM, Wu X, Broker TR, Chow LT. 1988. Post-transcriptional induction of $\mathrm{p} 21$ cip1 protein by human papillomavirus E7 inhibits unscheduled DNA synthesis reactivated in differentiated keratinocytes. Oncogene, 17: 2027-2038.

Jung ID, Shin SJ, Lee MG, Kang TH, Han HD, Lee SJ, Kim WS, Kim HM, Park WS, Kim HW, Yun CH, Lee EK, Wu TC, Park 
YM. 2014. Enhancement of tumor-specific T cell-mediated immunity in dendritic cell-based vaccines by mycobacterium tuberculosis heat shock protein X. J Immunol, 193: 1233-1245.

Kho EY, Wang HK, Banerjee NS, Broker TR, Chow LT. 2013. HPV-18 E6 mutants reveal p53 modulation of viral DNA amplification in organotypic cultures. Proc Natl Acad Sci USA, 110: 7542-7549.

Lambert PF, Ozbun MA, Collins A, Holmgren S, Lee D, Nakahara T. 2005. Using an immortalized cell line to study the HPV life cycle in organotypic "raft" cultures. Methods Mol Med, 119: 141-155.

Lazarczyk M, Cassonnet P, Pons C, Jacob Y, Favre M. 2009. The EVER proteins as a natural barrier against papillomaviruses: a new insight into the pathogenesis of human papillomavirus infections. Microbiol Mol Biol Rev, 73: 348-370.

Lee SA, Belyaeva OV, Wu L, Kedishvili NY. 2011. Retinol dehydrogenase 10 but not retinol/sterol dehydrogenase(s) regulates the expression of retinoic acid-responsive genes in human transgenic skin raft culture. J Biol Chem, 286: 13550-13560.

Lin KY, Guarnieri FG, Staveley-O'Carroll KF, Levitsky HI, August JT, Pardoll DM, Wu TC. 1996. Treatment of established tumors with a novel vaccine that enhances major histocompatibility class II presentation of tumor antigen. Cancer Res, 56: 21-26.

Liu Y, You H, Hermonat PL. 2005. Studying the HPV life cycle in $3 \mathrm{~A}$ trophoblasts and resulting pathophysiology. Methods Mol Med, 119: 237-245

Martinez I, Gardiner AS, Board KF, Monzon FA, Edwards RP, Khan SA. 2008. Human papillomavirus type 16 reduces the expression of microRNA-218 in cervical carcinoma cells. Oncogene, 27: 2575-2582.

Maufort JP, Shai A, Pitot HC, Lambert PF. 2010. A role for HPV16 E5 in cervical carcinogenesis. Cancer Res, 70: 2924-2931.

McKenna DJ, Patel D, McCance DJ. 2014. miR-24 and miR-205 expression is dependent on HPV onco-protein expression in keratinocytes. Virology, 448: 210-216.

McLaughlin-Drubin ME, Meyers C. Propagation of infectious, high-risk HPV in organotypic "raft" culture. 2005. Methods Mol Med, 119: 171-186.

McLaughlin-Drubin ME, Münger K. 2009. Oncogenic activities of human papillomaviruses. Virus Res, 143: 195-208.

Melar-New M, Laimins LA. 2010. Human papillomaviruses modulate expression of microRNA 203 upon epithelial differentiation to control levels of p63 proteins. J Virol, 84: 5212-5221.

Meyers C, Frattini MG, Hudson JB, Laimins LA. 2002. Biosynthesis of human papillomavirus from a continuous cell line upon epithelial differentiation. Science, 257: 971-973.

Moody CA, Laimins LA. 2009. Human papillomaviruses activate the ATM DNA damage pathway for viral genome amplification upon differentiation. PLoS Pathog, 5: e1000605.

Moody CA, Laimins LA. 2010. Human papillomavirus oncoproteins: pathways to transformation. Nat Rev Cancer, 10: 550 560.

Ocadiz-Delgado R, Marroquin-Chavira A, Hernandez-Mote R, Valencia C, Manjarrez-Zavala ME, Covarrubias L, Gariglio P. 2009. Induction of focal epithelial hyperplasia in tongue of young BK6-E6/E7 HPV16 transgenic mice. Transgenic Res, 18: $513-527$.

Ojesina AI, Lichtenstein L, Freeman SS, Pedamallu CS, Imaz-Rosshandler I, Pugh TJ et al. 2014. Landscape of genomic alterations in cervical carcinomas. 2014. Nature, 506: 371-375.

Park JW, Shin MK, Lambert PF. 2014. High incidence of female reproductive tract cancers in FA-deficient HPV16-transgenic mice correlates with E7's induction of DNA damage response, an activity mediated by E7's inactivation of pocket proteins.
Oncogene, 33: 3383-3391.

Park JW, Shin MK, Pitot HC, Lambert PF. 2013. High incidence of HPV-associated head and neck cancers in FA deficient mice is associated with E7's induction of DNA damage through its inactivation of pocket proteins. PLoS One, 8: e75056.

Peng S, Wang JW, Karanam B, Wang C, Huh WK, Alvarez RD, Pai SI, Hung CF, Wu TC, Roden RB. 2015. Sequential cisplatin therapy and vaccination with HPV16 E6E7L2 fusion protein in saponin adjuvant GPI-0100 for the treatment of a model HPV $1^{6+}$ cancer. PLoS One, 10: e116389.

Regan JA, Laimins LA. 2013. Viral transformation of epithelial cells. Methods Mol Biol, 945: 449-465

Sankovski E, Männik A, Geimanen J, Ustav E, Ustav M. 2014. Mapping of beta papillomavirus human papillomavirus 5 transcription and characterization of viral-genome replication function. J Virol, 88: 961-973.

Sarkola ME, Grénman SE, Rintala MA, Syrjänen KJ, Syrjänen SM. 2008. Human papillomavirus in the placenta and umbilical cord blood. Acta Obstet Gynecol Scand, 87: 1181-1188.

Schütze DM, Kooter JM, Wilting SM, Meijer CJ, Quint W, Snijders PJ, Steenbergen RD. 2015. Longitudinal assessment of DNA methylation changes during HPVE6E7-induced immortalization of primary keratinocytes. Epigenetics, 10: 73-81.

Shishodia G, Verma G, Srivastava Y, Mehrotra R, Das BC, Bharti AC. 2014. Deregulation of microRNAs Let-7a and miR-21 mediate aberrant STAT3 signaling during human papillomavirus-induced cervical carcinogenesis: role of E6 oncoprotein. BMC Cancer, 14: 996.

Siolas D, Hannon GJ. 2013. Patient-derived tumor xenografts: transforming clinical samples into mouse models. Cancer Res, 73: 5315-5319.

Son J, Park JW, Lambert PF, Chung SH. 2014. Requirement of estrogen receptor alpha DNA-binding domain for HPV oncogene-induced cervical carcinogenesis in mice. Carcinogenesis, 35: 489-496.

Stanley MA, Browne HM, Appleby M, Minson AC. 1989. Properties of a non-tumorigenic human cervical keratinocyte cell line. Int J Cancer, 43: 672-676.

Stanley JR, Yuspa SH. 1983. Specific epidermal protein markers are modulated during calcium-induced terminal differentiation. J Cell Biol, 96: 1809-1814.

Steenbergen RD, Parker JN, Isern S, Snijders PJ, Walboomers JM, Meijer CJ, Broker TR, Chow LT. 1998. Viral E6-E7 transcription in the basal layer of organotypic cultures without apparent $\mathrm{p} 21$ cip1 protein precedes immortalization of human papillomavirus type 16- and 18-transfected human keratinocytes. J Virol, 72: 749-757.

Stelzer MK, Pitot HC, Liem A, Schweizer J, Mahoney C, Lambert PF. 2010. A mouse model for human anal cancer. Cancer Prev Res (Phila), 3: 1534-1541.

Thomas MK, Pitot HC, Liem A, Lambert PF. 2011. Dominant role of HPV16 E7 in anal carcinogenesis. Virology, 421: 114-118.

Tran le S, Bergot AS, Mattarollo SR, Mittal D, Frazer IH. 2014. Human papillomavirus E7 oncoprotein transgenic skin develops an enhanced inflammatory response to 2,4-dinitrochlorobenzene by an arginase-1-dependent mechanism. J Invest Dermatol, 134:2438-2446.

Viarisio D, Decker KM, Aengeneyndt B, Flechtenmacher C, Gissmann L, Tommasino M. 2013. Human papillomavirus type 38 E6 and E7 act as tumor promoters during chemically induced skin carcinogenesis. J Gen Virol, 94: 749-752.

Walboomers JM, Jacobs MV, Manos MM, Bosch FX, Kummer JA, Shah KV et al. 1999. Human papillomavirus is a necessary cause of invasive cervical cancer worldwide. J Pathol, 189: $12-19$. 
Wald AI, Hoskins EE, Wells SI, Ferris RL, Khan SA. 2011. Alteration of microRNA profiles in squamous cell carcinoma of the head and neck cell lines by human papillomavirus. Head Neck, 33: 504-512.

Wang HK, Duffy AA, Broker TR, Chow LT. 2009. Robust production and passaging of infectious HPV in squamous epithelium of primary human keratinocytes. Genes Dev, 23: 181-194.

Wang X, Meyers C, Wang HK, Chow LT, Zheng ZM. 2011. Construction of a full transcription map of human papillomavirus type 18 during productive viral infection. J Virol. 85: 8080-8092.

Wang X, Tang S, Le SY, Lu R, Rader JS, Meyers C, Zheng ZM. 2008. Aberrant expression of oncogenic and tumor-suppressive microRNAs in cervical cancer is required for cancer cell growth. PLoS One, 3: e2557.

Wang X, Wang HK, Li Y, Hafner M, Banerjee NS, Tang S, Briskin D, Meyers C, Chow LT, Xie X, Tuschl T, and Zheng ZM. 2014. miRNAs are biomarkers of oncogenic HPV infections, Proc Natl Acad Sci U S A, 111: 4362-4267.

Wang X, Wang HK, McCoy JP, Banerjee NS, Rader JS, Broker TR, Meyers C, Chow LT, Zheng ZM. 2009. Oncogenic HPV infection interrupts the expression of tumor-suppressive miR34a through viral oncoprotein E6. RNA, 15: 637-647.

Wilson JL, Dollard SC, Chow LT, Broker TR. 1992. Epithelial-specific gene expression during differentiation of stratified primary human keratinocyte cultures. Cell Growth Diff, 3:
471-483.

Wilson R, Laimins LA. 2005. Differentiation of HPV-containing cells using organotypic "raft" culture or methylcellulose. Methods Mol Med, 119:157-69.

Xu H, Pirisi L, Creek KE. 2015. Six1 overexpression at early stages of HPV16-mediated transformation of human keratinocytes promotes differentiation resistance and EMT. Virology, 474: 144-153.

Yablonska S, Hoskins EE, Wells SI, Khan SA. 2013. Identification of miRNAs dysregulated in human foreskin keratinocytes (HFKs) expressing the human papillomavirus (HPV) Type 16 E6 and E7 oncoproteins. Microrna, 2: 2-13.

You H, Liu Y, Agrawal N, Prasad CK, Edwards JL, Osborne AF, Korourian S, Lowery CL, Hermonat PL. 2008. Multiple human papillomavirus types replicate in 3A trophoblasts. Placenta, 29: 30-38.

Zhang J, Li S, Yan Q, Chen X, Yang Y, Liu X, Wan X. 2013. Interferon- $\beta$ induced microRNA-129-5p down-regulates HPV18 E6 and E7 viral gene expression by targeting SP1 in cervical cancer cells. PLoS One, 8: e81366.

Zheng ZM, Wang X. 2011. Regulation of cellular miRNA expression by human papillomaviruses. Biochim Biophys Acta, 1809: $668-677$.

zur Hausen H. 2009. Papillomaviruses in the causation of human cancers - a brief historical account. Virology, 384:260-265. 